Nat. Hazards Earth Syst. Sci., 20, 1969-1983, 2020

https://doi.org/10.5194/nhess-20-1969-2020

(C) Author(s) 2020. This work is distributed under

the Creative Commons Attribution 4.0 License.

\title{
Natural hazard impacts on transport infrastructure in Russia
}

\author{
Elena Petrova \\ Faculty of Geography, Lomonosov Moscow State University, Moscow, 119991, Russia \\ Correspondence: Elena Petrova (epgeo@mail.ru)
}

Received: 25 December 2019 - Discussion started: 23 January 2020

Revised: 16 June 2020 - Accepted: 17 June 2020 - Published: 15 July 2020

\begin{abstract}
The transport infrastructure of Russia is exposed to multiple impacts of various natural hazards and adverse weather phenomena such as heavy rains and snowfalls, river floods, earthquakes, volcanic eruptions, landslides, debris flows, snow avalanches, rockfalls, and ice phenomena. The paper considers impacts of hazardous natural processes and phenomena on transport within the area of Russia. Using the information of the author's database, contributions of natural factors to road, railway, air, and water transport accidents and failures are assessed. The total risk of transport accidents and traffic disruptions triggered by adverse and hazardous natural impacts, as well as the risk of road and railway accidents and disruptions as the most popular modes of transport, is assessed at the level of Russian federal regions. The concept of an emergency situation is used to measure risk. In the risk analysis, 838 emergency situations of various scales and severity caused by natural hazard impacts on the transport infrastructure from 1992 to 2018 are considered. The average annual number of emergencies is taken as an indicator of risk. Regional differences in the risk of transport accidents and disruptions due to natural events are analyzed. Regions most at risk are identified.
\end{abstract}

\section{Introduction}

According to the federal law "On Transport Security" (2019), transport infrastructure of the Russian Federation (RF) is considered a large and complex technological system including tunnels, overpasses, and bridges; terminals and stations; river and sea ports; airports; and roads, railways, and waterways, as well as other buildings, structures, and equipment, ensuring the functioning of the transport system. Russia has a very extensive transportation network that is among the largest in the world. It includes $1.5 \times 10^{6} \mathrm{~km}$ of public roads, more than $600000 \mathrm{~km}$ of airways, $123000 \mathrm{~km}$ of railway tracks, and $100000 \mathrm{~km}$ of inland navigable waterways (FSSS, 2018).

In studies on the impacts of natural hazards, transport infrastructure is most often classified by mode of transport including road, rail, water, and air transport (e.g., Govorushko, 2012; Mattsson and Jenelius, 2015; Voumard et al., 2018). Some researchers classify it by infrastructure asset types. For example, Kaundinya et al. (2016) select such transport assets as bridges, tunnels, embankments, cuts, and centralized systems. This analysis is structured by mode of transport.

Due to the large length of the transportation network, as well as climatic, geological, geomorphologic, and other natural features of the country, transport infrastructure facilities of Russia are exposed to the undesirable impacts of adverse natural processes and phenomena, as well as to natural hazards of various geneses, such as geophysical and hydrometeorological. The distribution of various natural hazards across the country area is discussed below in Sect. 2.1. Their impacts may endanger transport safety and reliability, trigger accidents and failures, disrupt the normal operation of the transport system, cause delays in the delivery of passengers and goods, and lead to other negative consequences.

Natural processes and phenomena can be classified in various ways depending on the objectives of a study. Natural hazards can be typified according to their genetic features (e.g., Voumard et al., 2018), the intensity of their manifestation, the main formation and development factors, characteristics of spatial distribution and mode, etc. (Malkhazova and Chalov, 2004). Liu et al. (2016) propose a systematic natural hazard interaction classification based on the hazardforming environment. Gill and Malamud (2016) propose a detailed classification of natural hazard types in Guatemala, including six natural hazard groups (geophysical, hydrolog- 


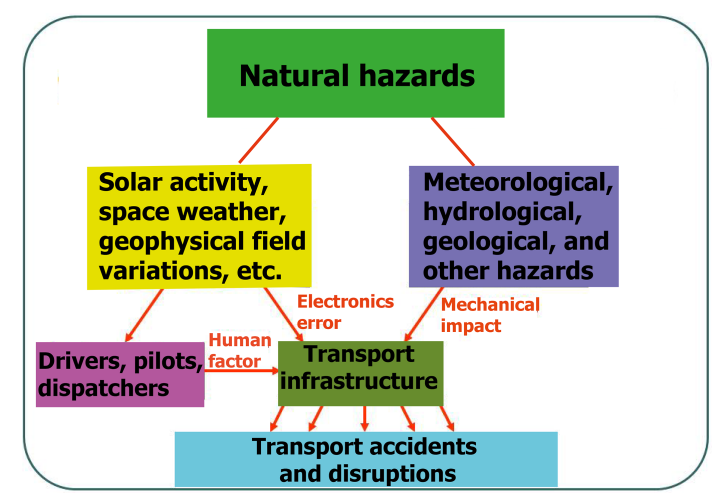

Figure 1. Grouping of natural hazards based on their genesis and impacts on transport infrastructure.

ical, shallow-Earth processes, atmospheric, biophysical, and space), 19 hazard types, and 37 hazard subtypes.

Previously, two types of natural hazards were found by the author, based on their genesis, distribution in space and time, and their impact pattern on the technosphere and society in populated areas (Petrova, 2005). In the context of the present study, the proposed classification scheme was adapted taking into account impacts of natural hazards on the transport infrastructure (Fig. 1).

Solar and geomagnetic disturbances (space weather), geodynamics, geophysical and astrophysical field variations, and other global processes belong to the first group. They have a global scale in space and cyclic development in time. Natural processes of this type may influence the transport infrastructure both directly, causing electronics error and automaticmachinery failure, and indirectly, by affecting the nervous system of operators, drivers, or pilots and thereby leading to a decrease in their reliability. Natural hazards of the second type are of a more "earthly" origin, i.e., from the atmosphere, lithosphere, hydrosphere, or biosphere. They vary greatly in their spatial scale and geographical location. These types of natural hazards include earthquakes, volcanic eruptions, landslides, snow avalanches, hurricanes, windstorms, heavy rains, hail, lightning, snow and ice storms, temperature extremes, wildfires, floods, and droughts. Natural hazards belonging to this group cause a direct destructive effect leading to accidents and disruptions.

A transport accident is any accident that occurs when people and goods are transported. With over 1.2 million people killed each year, road accidents are among the world's leading causes of death; another 20-50 million people are injured each year on the world's roads (WHO, 2017). Transport accidents of other types including air, rail, and water transport are not as numerous as road crashes, but the severity of their consequences is much higher because of the higher number of people killed and injured per accident. Shipwrecks with a large number of passengers have the highest number of casualties.
Traffic interruptions and disruptions cause multiple social problems because our societies are highly dependent on transport systems for people's daily mobility and for goods transport (Mattsson and Jenelius, 2015). In the case of an emergency situation, a transport network serves as a lifeline system. Thus, ensuring the robustness and reliability of the transport system is one of the most important and pressing problems of the socio-economic development of any country. In May 2018, the Ministry of Transport of the RF developed a new version of the transport strategy for up to 2030 (Ministry of Transport of the Russian Federation, 2018). Among the key priorities, the Transport strategy includes requirements to cope with modern challenges, such as climate change and a need for increasing the safety of the transport system.

Since the early 1950s (Tanner, 1952), it has been recognized that weather conditions affect many road safety aspects such as driver attention and behavior, vehicle operation, and road surface condition. A large number of studies devoted to the influence of weather factors on accident rates have been published over the last few decades. All the authors agree that adverse weather is a major factor affecting road situations (e.g. Edwards, 1996; Rakha et al., 2007; Andrey, 2010; Andersson and Chapman, 2011; Bergel-Hayat et al., 2013; Chakrabarty and Gupta, 2013; Yang et al., 2013). Many authors connect the maximum number of road accidents with precipitation (Jaroszweski and McNamara, 2014; Spasova and Dimitrov, 2015). Aron et al. (2007) revealed that $14 \%$ of all injury accidents in Normandy (France) took place during rainy weather and $1 \%$ during fog, frost, or snow and hail. Satterthwaite (1976) found rainy weather to be a major factor affecting accident numbers on the state highways of California: on very wet days the number of accidents was often double comparing to dry days. Brodsky and Hakkert (1988) with data from Israel and the USA indicated that the added risk of an injury accident in rainy conditions can be 2 to 3 times greater than in dry weather; when rain follows a dry spell, the hazard could be even greater. Among other weather factors, bright sunlight has been identified as a cause of accidents (Shiryaeva, 2016). Redelmeier and Raza (2017) investigated visual illusions created by bright sunlight that lead to driver error, including fallible distance judgment from an aerial perspective. According to their results, the risk of a life-threatening crash was $16 \%$ higher during bright sunlight than normal weather.

Some authors consider other natural hazards, such as landslides (Bíl et al., 2014; Schlögl et al., 2019), flash floods (Shabou et al., 2017), or rockfalls (Bunce et al., 1997; Budetta and Nappi, 2013).

As for railway transport, most papers also focus on specific hazards, considering impacts of adverse weather and hydrometeorological extremes (Ludvigsen and Klæboe, 2014; Nogal et al., 2016), landsliding (Jaiswal and van Westen, 2013), flooding (Hong et al., 2015; Kellermann et al., 2016), snowfall (Ludvigsen and Klæboe, 2014), or tree falls (Ny- 
berg and Johansson, 2013; Bil et al., 2017) as triggers of accidents.

Some studies combine all types of natural hazards affecting road and rail infrastructure (Govorushko, 2012; Petrova, 2015; Kaundinya et al., 2016). Voumard et al. (2018) examine small events like earth flow, debris flow, rockfall, flood, and snow avalanche, which represent three-quarters of the total direct costs of all natural hazard impacts on Swiss roads and railways.

Investigations of natural hazard impacts on transport systems other than roads and railways are not so numerous. As an example, studies about the danger of volcanic eruptions to aviation should be mentioned (Neal et al., 2009; Brenot et al., 2014; Girina et al., 2019). Large explosive eruptions of volcanoes can eject several cubic kilometers of volcanic ash and aerosol into the atmosphere and stratosphere during a few hours or days, posing a threat to modern airliners (Gordeev and Girina, 2014).

Only a few studies have investigated impacts of global processes, such as geomagnetic storms (space weather) and seismic activity. In the early 1990s, Epov (1994) found a correlation $(R=0.74)$ between solar activity and the temporal distribution of air crashes. Desiatov et al. (1972) argue that the number of road accidents multiplies by 4 on the second day after a solar flare in comparison to "inactive" solar days. According to Miagkov (1995), solar activity affects operators, drivers, pilots, etc., causing a "human error" and "human factor" in accidents. Kanonidi et al. (2002) study a relationship between disturbances of the geomagnetic field and the failure of automatic railway machinery. Kishcha et al. (1999) and Anan'in and Merzlyi (2002) examine a correlation between seismic activity and air crashes.

The main purpose of this study is to investigate impacts of natural hazards on the transport infrastructure and transport facilities in Russian regions. Using the information collected by the author in the database of technological and naturaltechnological accidents, contributions of natural factors to road, railway, air, and water transport accident occurrences and traffic disruptions are assessed. All types of natural hazards are considered excluding impacts of global processes (left side in Fig. 1) that are not listed in the database. The risk of road and railway accidents and traffic disruptions, as well as the total risk of transport accidents and disruptions, caused by adverse and hazardous natural events is estimated for the area of Russia.

\section{Materials and methods}

\subsection{Study region}

The Russian Federation is the study region.

Federal regions (constituent entities) of the RF were taken as basic territorial units for which all the calculations were performed during the analysis. Federal regions are the main administrative units of the Russian Federation; at this territorial level, all official statistics are published by the Federal State Statistics Service (FSSS) and other federal institutions of Russia.

The main administrative units of the RF include 85 federal regions: 22 republics, 9 territories (krais), 46 regions (oblasts), 1 autonomous region (autonomous oblast or AR, i.e., Jewish AR), and 4 autonomous areas (autonomous okrugs; AOs). Moscow, Saint Petersburg, and Sevastopol have a special status as federal cities (FCs; cities of federal importance or significance). All the federal regions mentioned in the paper are indicated in Fig. 2.

The size and geographical location of the Russian Federation in various climate and geological conditions determine a great variety of dangerous natural processes and phenomena in its area, including endogenous, exogenous, and hydrometeorological hazards. The most characteristic features of the geography of natural hazards in Russia are as follows:

- Natural hazards associated with cold and snowy winters are common throughout the country.

- The population and the economy are relatively little exposed to the most destructive types of natural hazards (earthquakes, tsunamis, hurricanes, etc.), and therefore the frequency of occurrence of natural emergencies with severe consequences is low.

- The historically formed strip of the main settlements from the European part of Russia through the south of Siberia to the Far East approximately coincides with the zone of the smallest manifestation of natural hazards (Miagkov, 1995).

In Russia, there are several hundred volcanoes, 78 of which are active. Kamchatka and the Kuril Islands are most at risk of volcanic eruptions; explosive eruptions of two to eight volcanoes are observed annually (Girina et al., 2019). About $20 \%$ of the country area with a population of 20 million people is exposed to earthquakes. The most seismically active regions are Kamchatka and Sakhalin, as well as the south of Siberia and the North Caucasus.

Almost the entire territory of Russia is exposed to dangerous exogenous processes; their intensity increases from north to south and from west to east (EMERCOM, 2010). Among exogenous processes, landslides, which are active in $40 \%$ of the country area; debris flows (in $20 \%$ ); snow avalanches (in more than $18 \%$ of the area); and other slope processes have the greatest intensity and negative impact on the transport infrastructure. The highest avalanche and debris flow activity is observed in the North Caucasus (republics of Dagestan, North Ossetia - Alania, and KabardinoBalkaria) and in Sakhalin. The greatest intensity of landslides is in the North Caucasus (Chechen, Kabardino-Balkaria, and Karachay-Cherkessia republics; republics of Dagestan, Ingushetia, and North Ossetia - Alania; Stavropol and 


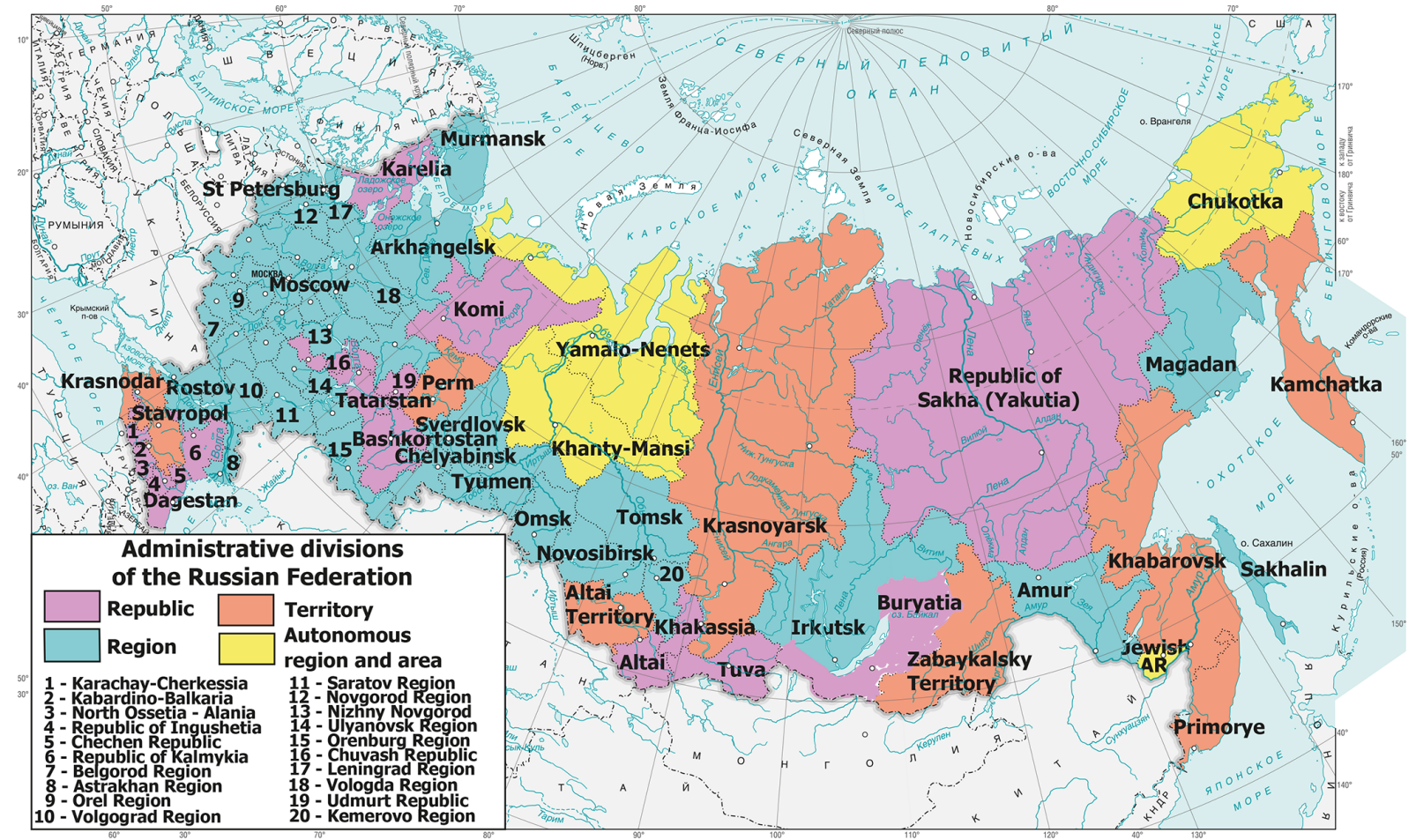

Figure 2. Federal regions of the Russian Federation (base map ( DIK - Publishing House: Design. Information. Cartography).

Krasnodar territories; Rostov Region) and Ural (Chelyabinsk and Sverdlovsk regions), as well as in the Khabarovsk and Primorye territories and the Amur, Irkutsk, and Sakhalin regions.

Hydrometeorological hazardous processes and phenomena such as strong winds, squalls, catastrophic showers, floods, snowstorms, thunderstorms, and hailstorms are widespread in the country. The combination of heavy precipitation and strong wind is one of the most dangerous climate situations in the coastal regions of the Far East (Sakhalin Region; Kamchatka, Khabarovsk, and Primorye territories). The highest frequency of strong winds is observed in the south and in the middle part of European Russia, as well as in the Far East. The most intense rains take place in the Kamchatka, Krasnodar, and Primorye territories; the heaviest snowfalls happen in regions of the North Caucasus and north and southwest of Siberia, as well as in the Far East (Sakhalin and Magadan regions; Chukotka; Kamchatka, Khabarovsk, and Primorye territories). Regions of the Far East, such as the Republic of Sakha (Yakutia), Khabarovsk and Primorye territories, and Amur Region, as well as south of European Russia (republics in the North Caucasus; Krasnodar and Stavropol territories), are most exposed to catastrophic floods.

For Russia as a whole, the cumulative degree of natural hazard increases from west to east and south, with progression to the mountainous regions. The most dangerous areas in terms of manifestations of natural hazards are situated in the North Caucasus; Ural and Altai mountains; Irkutsk Region and Zabaykalsky Territory; the Pacific coast of the Far East (Khabarovsk Territory and Magadan Region); and especially Sakhalin, the Kuril Islands, and Kamchatka (Malkhazova and Chalov, 2004).

According to the assessment by EMERCOM (2010), the following federal regions are the most vulnerable to the impacts of natural hazards: the republics of Sakha (Yakutia), Karelia, and Komi; Khabarovsk and Primorye territories; and Amur, Arkhangelsk, Irkutsk, Magadan, Murmansk, and Volgograd regions, as well as the Jewish AR, Khanty-Mansi Autonomous Area - Yugra, and Chukotka AO. The vulnerability is measured as a ratio of the total number of realized natural sources of emergencies to the number of emergency situations caused by them. In the listed regions, the vulnerability is higher than the average for Russia.

\subsection{Methodology}

An assessment was made of the risk of road and railway accidents and traffic disruptions, as well as of the total risk of transport accidents and disruptions, caused by adverse and hazardous natural impacts on the transport infrastructure in Russian federal regions. Road, rail, air, and water transport were considered in the total risk analysis.

Risk is understood as the possibility of undesirable consequences of any action or course of events (Miagkov, 1995). Risk is measured by the probability of such consequences or the probable magnitude of loss. 
There are various methods for assessing risk. In the field of natural hazards, risk is generally defined as the product of hazard and vulnerability, i.e., a combination of the damaging phenomenon and its consequences (Eckert et al., 2012). Most researchers calculate risk $(R)$ as a function of hazard $(H)$, exposure $(E)$, and vulnerability $(V): R=f(H, E, V)$ (e.g., Arrighi et al., 2013; Falter et al., 2015; IPCC, 2012; Schneiderbauer and Ehrlich, 2004). Various authors propose their own techniques for calculating risk (Eidsvig et al., 2017), mainly within the framework of this common approach. In a recent publication, Arosio et al. (2020) propose a holistic approach to analyze risk in complex systems based on the construction and study of a graph modeling connections between elements.

Another approach to measuring risk suggests using the concept of an emergency situation. In Russia, an emergency situation is defined as a disturbance of the current activity of a populated region due to abrupt technological or natural impacts (catastrophes or accidents) resulting in social, economic, and/or ecological damage, which requires special management efforts to eliminate it (Petrova, 2005). An emergency situation caused by the impact of natural hazards on technological systems and infrastructure can be considered as a result of all the factors of risk: hazard, exposure, and vulnerability. It combines hazard defined by its physical parameters, exposure of a population or facilities located in a hazard area and subject to potential loss, and vulnerability that links the intensity of a hazard to undesirable consequences. An emergency resulting from a hazardous impact may be a measure of the loss due to this impact. The total frequency of emergencies of varying severity may serve as a comprehensive indicator of risk assessment (Shnyparkov, 2004).

In this study, the above approach using the frequency of emergency situations as a measure of risk was applied. As an indicator of risk, the average frequency of occurrence of transport accidents and traffic disruptions triggered by natural hazard impacts, which led to emergency situations of different scales and severity, was used. Risk indicators were calculated for each federal region as average annual numbers of emergency situations for each type of transport, as well as a resulting average annual number of emergencies due to all transport accidents and disruptions. Thus, the calculated indicators included the probability of undesirable consequences (emergencies) due to impacts of natural hazards on transport infrastructure exposed and vulnerable to these influences. Quantitative and qualitative criteria for classifying transport accidents and disruptions as emergency situations are listed below.

The information collected by the author in an electronic database of technological and natural-technological accidents (created using Microsoft Access) is analyzed in this study. Figure 3 shows the relational structure of the database and the procedure for conducting data analysis.

The database is constantly updated with new information (Petrova, 2011). Currently, it contains about 20000 events

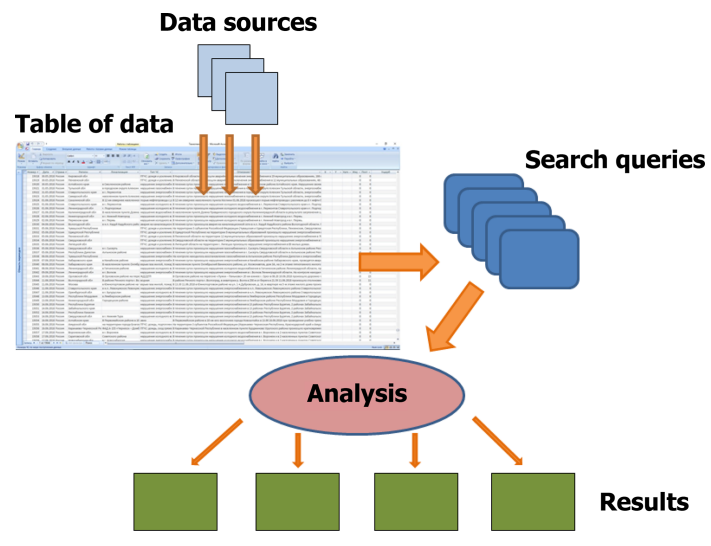

Figure 3. Relational structure of the database.

from 1992 to 2018. Official daily emergency reports of EMERCOM (the Ministry of the Russian Federation for Affairs for Civil Defence, Emergencies and Elimination of Consequences of Natural Disasters) and media reports serve as data sources. Only open data are used. Emergency reports are publicly available on the EMERCOM website (https: //www.mchs.gov.ru, last access: 20 June 2020) but only in Russian.

The format of the database makes it possible to structure the collected information and classify it according to the author's assessment. The main database table, into which all the information is entered, has the following structure (the listed sections correspond to the column names of the table in Fig. 3):

1. event number - the number changes automatically as information is entered;

2. date of the incident;

3. country;

4. region;

5. location - the distance to the nearest settlement is additionally indicated;

6. type of accident - according to the EMERCOM classification and assessment by the author;

7. a brief description of the event, including the time of occurrence, probable cause of the accident if available, its consequences, and measures taken to eliminate these consequences;

8. geographical coordinates if applicable;

9. the scale of the emergency situation caused by the accident - local, intermunicipal, regional, inter-regional, cross-border;

10. the number of deaths; 
11. the number of injuries;

12. economic and environmental loss if any;

13. source of information.

All types of technological accidents occurring in Russia are recorded in the database, including those triggered by impacts of natural events of various geneses. Such accidents in technological systems and infrastructure due to natural impacts are classified as natural-technological. The transport accidents and traffic interruptions caused by natural hazards are also listed.

It should be noted that it is not possible to fully cover all the accidents in the database, because they are too numerous, especially road accidents. According to the state traffic inspectorate of the Ministry of Internal Affairs of Russia, 168000 road accidents were registered in the RF in 2019.

The criteria for statistical accounting and reporting information about transport accidents by EMERCOM are as follows:

1. for road accidents,

- any fact of an accident during the transportation of dangerous goods;

- damage to $\geq 10$ motor units;

- traffic interruptions for $12 \mathrm{~h}$ due to an accident;

- severe accidents with the death of $\geq 5$ people or $\geq$ 10 people injured;

2. for railway accidents,

- any fact of a train crash;

- damage to wagons carrying dangerous goods, causing people to be injured;

- traffic interruptions on the main railway tracks for $6 \mathrm{~h}$ or more or on the subway for 30 min or more;

3. for air transport accidents, any fact of an aircraft fall or destruction;

4. for water transport accidents,

- emergency release of oil and oil products into water bodies of the amount of $\geq 1 \mathrm{t}$;

- accidental ingress of liquid and loose toxic substances into water bodies exceeding the maximum permissible concentration by $\geq 5$ times;

- any fact of flooding or throwing of ships ashore as a result of a storm (hurricane, tsunami) or running of ships aground;

- accidents on small vessels with the death of $\geq 5$ people or $\geq 10$ people injured;

- accidents on small vessels carrying dangerous goods.
The same selection criteria are used for events to be included in the author's database. Events that meet these criteria are characterized as emergency situations.

The accumulation of all the information in the form of an electronic database allows for conducting various thematic search queries and analyzing their results depending on the goals and objectives of the research (Fig. 3).

For the purposes of this study, a search of information about transport accidents and traffic disruptions caused by the impacts of natural hazards was made. Road, rail, air, and water transport were included in separate search queries. Statistical and geographical analysis of data obtained as a result of these search queries was carried out.

The proportion of accidents and disruptions triggered by natural factors was evaluated. All types of natural hazards and adverse weather conditions were taken into account. The main natural causes of accidents and failures were identified for each mode of transport.

Additionally, all the federal regions were divided into groups according to their risk level. The risk level was estimated for each federal region and each type of transport by the average annual number of emergency situations in comparison with the average value of the indicator in Russia. The number of groups was determined in each case depending on the dispersion of the calculated value. For the analysis, the period from 1992 to 2018 was chosen, since it covered data accumulated in the database.

Using the cartogram method, maps were created, on which the results of the assessment were presented (Figs. 4-6).

\section{Results}

\subsection{Contributions of natural hazards}

The transport infrastructure of Russia is exposed to multiple impacts of various natural hazards and weather phenomena such as heavy rains and snowfalls, strong winds, floods, earthquakes, volcanic eruptions, landslides, debris flows, snow avalanches, rockfalls, and icy conditions of roads. In many cases, these impacts occur simultaneously or successively, one after another, and reinforce each other. Some natural hazards trigger hazards of other types, e.g., an earthquake or volcanic eruption can provoke such slope processes as rockfalls, ice collapses, landslides, debris flows and lahars, and snow avalanches; heavy rain can cause debris flows, landslides, or floods, etc. Gill and Malamud (2016) examine hazard interrelationships in more detail. These triggering impacts are also recorded in the database and taken into account in the analysis.

Contributions of various natural factors to occurrences of different types of transport accidents and traffic disruptions including road, railway, air, and water transport were found as the result of relevant searches in the database. Table 1 shows these results. The "+" sign marks impacts of natural 
Table 1. Transport accidents and traffic disruptions caused by natural hazards in Russia (1992-2018).

\begin{tabular}{lcccc}
\hline Natural hazard & \multicolumn{4}{c}{ Type of transport } \\
\cline { 2 - 5 } & $\begin{array}{c}\text { Road } \\
\text { transport }\end{array}$ & $\begin{array}{c}\text { Railway } \\
\text { transport }\end{array}$ & $\begin{array}{c}\text { Air } \\
\text { transport }\end{array}$ & $\begin{array}{c}\text { Water } \\
\text { transport }\end{array}$ \\
\hline Strong wind, storm & & & + & + \\
Snowfall, snowstorm, snowdrift, sleet & + & + & + & + \\
Rainfall, hail & + & + & + & + \\
Hard frost, icing, ice-crusted ground & + & & + & + \\
Thunderstorm, lightning & + & & + & + \\
Fog, mist & + & + & & \\
Flood & + & + & & \\
Heat wave & + & + & & \\
Earthquake, volcanic eruption & + & + & & \\
Landslide, slump, debris flow & + & + & + & \\
Rockfall & + & & & \\
Snow avalanche & & & & \\
\hline
\end{tabular}

hazards listed in the first column on the corresponding type of transport. Only accidents and disruptions that occurred in Russia and were recorded in the database are taken into consideration.

As the analysis of the database revealed, the transport infrastructure of Russia is most often affected by adverse impacts of meteorological and hydrological origin, especially by hazards associated with cold and snowy winters, as well as exogenous slope processes including those provoked by hydrometeorological hazards. The majority of emergency situations due to natural hazards are registered from November to March (>67\%); among the warmer months, the largest number of transport accidents occurs in July.

The frequencies of occurrence of accidents and disruptions caused by the impacts of natural hazards, as well as their proportion among other factors of accidents, are discussed in the following sections.

\subsubsection{Road transport}

Road transport is one of the main means of moving passengers and goods over short and medium distances in Russia. In terms of transport security, it is the most dangerous means of transportation with the highest number of fatalities and injuries in accidents (Petrova, 2013) and one of the most common sources of technological hazard, as the number of cars on roads increases significantly faster than the quality of road infrastructure (EMERCOM, 2010).

More than $20 \%$ of road accidents and traffic disruptions registered in the database were caused by the impacts of various natural hazards. This refers to those incidents where natural impact was indicated as the main cause of the accident.

Road transport facilities and road infrastructure are exposed to adverse and hazardous natural processes and phenomena of hydrometeorological character practically all around Russia. Many sections of roads, bridges, and other road infrastructure are subject to impacts of snowfalls and snowstorms, heavy rainfalls, flooding, and road icing; from among exogenous hazards, landslides, debris flows, snow avalanches, rockfalls, and other natural hazards affect road infrastructure. These negative impacts trigger road accidents and traffic disruptions, leading to emergency situations and causing many social problems. Under unfavorable meteorological conditions, the risks of car crashes as well as delays in transportation, are increasing, while the speed of traffic flow is decreasing (Petrova and Shiryaeva, 2019).

For the study period from 1992 to 2018 , the following natural hazard impacts that caused accidents and traffic disruptions are identified. They are recorded in 70 of the 85 federal regions of Russia. The brackets indicate the regions where these accidents and failures occurred:

- heavy snowfall and snowdrift (Republic of Altai; Altai, Kamchatka, Khabarovsk, Krasnodar, Krasnoyarsk, Primorye, and Stavropol territories; Jewish AR; Yamalo-Nenets AO; Amur, Arkhangelsk, Astrakhan, Chelyabinsk, Magadan, Murmansk, Novosibirsk, Omsk, Orenburg, Rostov, Sakhalin, Saratov, Sverdlovsk, and Volgograd regions);

- bottom snowstorm (Bashkortostan and Komi republics; Altai, Kamchatka, and Krasnoyarsk territories; Chelyabinsk, Magadan, Murmansk, Orenburg, Sakhalin, Ulyanovsk, and Volgograd regions);

- ice phenomena (republics of Bashkortostan, Kalmykia, and Khakassia; Primorye and Khabarovsk territories; Jewish AR; Chelyabinsk, Leningrad, Magadan, Rostov, and Sakhalin regions);

- abnormally low air temperature (Yamalo-Nenets AO; Krasnoyarsk Territory; Kemerovo, Novosibirsk, Omsk, and Tomsk regions); 
- flooding of road due to heavy rain (Moscow FC; republics of Altai, Bashkortostan, Buryatia, Khakassia, Sakha (Yakutia), and Tuva; Chukotka AO; Altai, Krasnodar, Primorye, and Stavropol territories; Amur, Arkhangelsk, Leningrad, Magadan, Moscow, Nizhny Novgorod, Novgorod, Sakhalin, and Saratov regions);

- washout of road (Republic of Sakha (Yakutia), Kamchatka Territory, Sverdlovsk and Tyumen regions);

- debris flow (Chechen, Kabardino-Balkaria, KarachayCircassian, and North Ossetia - Alania republics; Krasnodar Territory; Sakhalin Region);

- snow avalanche (republics of Dagestan and North Ossetia - Alania);

- rockfall (republics of Dagestan and North Ossetia - Alania);

- volcanic eruption (Kamchatka Territory).

The majority of all the emergencies revealed (almost $73 \%$ ) happened during the cold season from November to March. A significant increase in their number occurred during abrupt changes in weather conditions, such as heavy precipitation, temperature drops, and icing. Emergency situations caused by snow-related natural hazards were most frequent and most common. Snowdrifts on the roads became a real disaster leading to long-term traffic disruptions in many regions of Russia, especially in the Arkhangelsk, Chelyabinsk, Novosibirsk, Omsk, Orenburg, Rostov, Sakhalin, and Sverdlovsk regions and the Altai, Khabarovsk, and Krasnodar territories.

The frequencies of occurrence of road accidents and disruptions due to natural hazards are discussed in Sect. 3.2.1.

\subsubsection{Railway transport}

In the Russian Federation, due to its vast and extended territory and natural features and large distances of raw material bases from processing enterprises, railway transportation is the basis of the transport system. It accounts for $>80 \%$ of the freight turnover of all types of transport (without pipelines) and $>40 \%$ of the passenger traffic of public transport in long-distance and suburban communications. Railway transport is considered the safest form of modern transportation, although railway catastrophes with a large number of victims and injuries occur in many countries. The main causes of railway accidents in Russia are technical problems, a high degree of depreciation (of tracks, rolling stocks, signaling means, and other equipment) and human factors such as errors of dispatchers and drivers (Petrova, 2015).

More than $7 \%$ of all railway accidents and failures registered in the database were triggered by natural factors. This refers to those incidents where natural impacts were indicated as the main causes of accidents. From 1992 to 2018, impacts of natural hazards of various geneses caused railway accidents and traffic disruptions in 29 of the 85 federal regions of Russia.

The identified natural hazards that caused these harmful events are listed below. The brackets indicate the regions where these accidents and failures occurred:

- heavy snow (Yamalo-Nenets AO, Orenburg and Sakhalin regions);

- washout of railway as a result of heavy rain and flash flood (republics of Dagestan and Karelia, Chuvash and Udmurt republics, Khabarovsk and Krasnodar territories, Amur and Sakhalin regions);

- snow avalanche (Khabarovsk Territory, Sakhalin Region);

- rail deformation due to heat wave (Republic of Kalmykia, Rostov Region);

- landslide (Krasnodar Territory, Orel Region);

- debris flow (Krasnodar Territory, Sakhalin Region);

- rockfall (Republic of Bashkortostan, Khabarovsk and Krasnodar territories);

- flooding due to melting snow (Murmansk and Vologda regions).

Regarding the seasonality of accidents, they had two peaks: in summer (in June and July) and in November. Most emergency situations were caused by snowdrifts and washout or flooding of railway tracks due to heavy rains or floods, as well as by the slope processes such as landslides, snow avalanches, debris flows, and rockfalls.

The frequencies of occurrence of railway accidents due to natural hazards are discussed in Sect. 3.2.2.

\subsubsection{Air transport}

Air transport is the fastest and most expensive mode of transportation. That is why it is primarily used to transport passengers over distances of more than $1000 \mathrm{~km}$. In many distant areas of Russia (in the mountains, in the Far North), it is the only means of transport. The main causes of accidents are technical failures or human errors, as well as various natural factors including adverse weather or collision with a flock of birds (EMERCOM, 2010).

The adverse weather conditions and other natural hazard impacts caused more than $8 \%$ of all the air transport accidents and traffic disruptions recorded in the database. This refers to those incidents where natural impacts were indicated as the main causes of accidents. From 1992 to 2018, these events were registered in 27 of the 85 federal regions of Russia.

The following impacts of natural hazards were revealed: 
- strong winds (Moscow FC; republics of Bashkortostan and Tatarstan; Chuvash Republic; Kamchatka, Krasnodar, and Krasnoyarsk territories; Irkutsk, Murmansk, Omsk, Rostov, Sakhalin, Saratov, and Ulyanovsk regions);

- thunderstorms (Republic of Sakha (Yakutia), Irkutsk Region);

- heavy rains (Moscow FC, Khabarovsk and Krasnodar territories, Irkutsk Region);

- snowfalls and snowstorms (Moscow FC; Republic of Khakassia; Kamchatka, Krasnodar, and Krasnoyarsk territories; Leningrad, Magadan, Rostov, and Sakhalin regions);

- sleet (Moscow and St Petersburg FCs, republics of Bashkortostan and Tatarstan, Chuvash Republic, Kamchatka and Krasnodar territories, Rostov Region);

- runway icing (Moscow FC, Kamchatka and Primorye territories, Kaluga and Murmansk regions);

- fog (Moscow FC, Chechen and Ingushetia republics, Sverdlovsk Region);

- snow avalanche (Kamchatka);

- volcanic eruption.

In many cases, these adverse impacts occurred simultaneously. Thus, the majority of emergency situations were caused by a combination of heavy snow and strong winds. Almost $66 \%$ of events occurred during the cold season from November to March; another peak of accidents was in July.

A unique incident, when a helicopter was damaged as a result of an avalanche, was recorded in the database on 10 April 2010 in Kamchatka.

For the study period, there was not a single accident caused by volcanic eruption in Russia. Due to the eruption of the Icelandic volcano Eyjafjallajökull, airlines canceled and delayed more than 500 flights at 10 Russian airports in April 2010; 32000 passengers could not fly.

The frequencies of occurrence of air transport accidents caused by natural hazards are discussed in Sect. 3.2.3 and included in the total risk analysis (Sect. 3.2.5).

\subsubsection{Water transport}

Water transport includes both sea and river transport. Despite the relatively low speed and seasonal limitations on traffic, this type of transport is widely used for transporting large volumes of goods and passengers over different distances. The main causes of accidents in water transport are violations of the rules of navigation and transportation and of fire safety and the technical operation of vessels; depreciation of ships, ports' equipment, and other objects of infrastructure; and impacts of natural hazards and adverse weather conditions (EMERCOM, 2010).

The greatest contribution of natural factors to the accident rate after road transport was recorded for water transport. Almost $16 \%$ of all the water transport accidents registered in the database were caused by various natural hazards. These events were registered in 21 of the 85 federal regions of Russia.

The following impacts were revealed from 1992 to 2018 :

- strong winds (Kamchatka, Krasnodar, and Primorye territories; Leningrad, Sakhalin, and Sverdlovsk regions);

- storms (republics of Dagestan, Karelia, and Tatarstan; Yamalo-Nenets AO; Kamchatka, Khabarovsk, Krasnodar, and Primorye territories; Astrakhan, Irkutsk, Magadan, Murmansk, Rostov, Ryazan, Sakhalin, and Yaroslavl regions);

- snowstorms (Irkutsk and Sakhalin regions);

- icing (Republic of Sakha (Yakutia), Primorye Territory, Sakhalin Region);

- thunderstorms (Komi Republic, Leningrad Region);

- fog and mist (Leningrad and Sakhalin regions).

Most accidents ( $>70 \%)$ occurred during the cold season from September to January.

The frequencies of occurrence of water transport accidents due to natural hazards are discussed in Sect. 3.2.4 and included in the total risk analysis (Sect. 3.2.5).

\subsection{Risk of transport accidents and traffic disruptions}

Occurrence frequencies of road, railway, air, and water accidents and traffic disruptions due to natural hazard impacts at the level of Russian federal regions were estimated for the risk analysis. As mentioned in Sect. 2.2, only accidents and disruptions which reached the scale of emergency situation were taken into account. Annual average numbers of such events from 1992 to 2018 were used as risk indicators.

All the federal regions were divided into groups by their risk levels of road and railway accidents, as well as by the total risk of transport accidents and traffic disruptions. In each case, the risk level was determined in comparison with the average value of the corresponding indicator for Russia.

The resulting maps were created and analyzed. Regional differences in the risk of transport accidents were found. Below are the main results of the risk analysis.

\subsubsection{Road transport}

The risk of emergencies in road transport depends on the density of the road network, traffic intensity, and human factors (violation of traffic rules by drivers and pedestrians, etc.), 
as well as climatic conditions, seasonality, and other circumstances. With its large area, the paved public road density in Russia is the lowest of all the G8 countries, equal to $63 \mathrm{~km}\left(1000 \mathrm{~km}^{2}\right)^{-1}$ (FSSS, 2020). However, it is much higher in the densely populated regions of the European part of Russia. In the Asian part, only some southwestern and southeastern regions have a satisfactory network of hardsurface roads (Petrova and Shiryaeva, 2019). Moscow and St Petersburg have the highest density of paved public roads, which comprises about $2500 \mathrm{~km}\left(1000 \mathrm{~km}^{2}\right)^{-1}$; it is also high in federal regions of central Russia (Moscow and Belgorod regions) and the North Caucasus (republics of Ingushetia and North Ossetia - Alania), equal to $700-850 \mathrm{~km}\left(1000 \mathrm{~km}^{2}\right)^{-1}$ (FSSS, 2020).

The risk of road accidents and traffic disruptions due to natural hazard impacts within the Russian federal regions was assessed.

For the risk analysis, 635 emergency situations of various scales and severity caused by the impacts of natural hazards on road infrastructure were taken into consideration. The main triggers of these emergencies and the regions of their occurrence were identified in Sect. 3.1.1. The risk indicator was calculated as an average annual number of emergency situations of this type in each federal region as well as the average for Russia.

All the federal regions are divided into five groups in accordance with risk level by comparing their risk indicators with the average for Russia. Figure 4 shows the resulting map.

Regions of the Far East of Russia (Kamchatka and Khabarovsk territories, Magadan and Sakhalin regions), Krasnoyarsk Territory in the southern part of central Siberia, and the Republic of North Ossetia - Alania in the North Caucasus have the highest risk level. The road infrastructure in these regions is most affected by the above-listed natural hazards, especially by heavy snowfalls and snowstorms, ice phenomena, abnormally low air temperature, and heavy rains. In North Ossetia - Alania, impacts of snow avalanches and debris flows are the most significant.

\subsubsection{Railway transport}

The risk of emergencies in railway transport depends on the density of the railway network, traffic intensity, human factors, climatic conditions, and seasonality. The highest density of the public railway network is in the federal cities of Moscow $\left(1921 \mathrm{~km}\left(10000 \mathrm{~km}^{2}\right)^{-1}\right)$ and St Petersburg $\left(3082 \mathrm{~km}\left(10000 \mathrm{~km}^{2}\right)^{-1}\right)$, as well as in federal regions of the central and northwestern parts of European Russia such as the Moscow, Kaliningrad, Tula, Kursk, Vladimir, and Leningrad regions $\left(300-500 \mathrm{~km}\left(10000 \mathrm{~km}^{2}\right)^{-1}\right)$. With a lack of railways in a large part of the country area, especially in its Asian part, the average density of railways in Russia is $51 \mathrm{~km}\left(10000 \mathrm{~km}^{2}\right)^{-1}$; in the central part of European Russia it is $263 \mathrm{~km}\left(10000 \mathrm{~km}^{2}\right)^{-1}$ (FSSS, 2020).
The risk of railway accidents and traffic disruptions due to natural hazard impacts at the level of Russian federal regions was assessed.

For the risk analysis, 63 emergency situations of various scales and severity caused by the impacts of natural hazards on railway infrastructure were taken into consideration. The main triggers of these emergencies and the regions of their occurrence were identified in Sect. 3.1.2. Occurrence frequencies (annual average numbers) of these events were calculated for each federal region as well as the average for Russia.

All the federal regions are divided into three groups by their risk levels. In this case, only three groups are chosen, since the number of accidents and dispersion of risk indicators are not as great as in the case of road accidents. Figure 5 shows the resulting map.

Krasnodar Territory in the southern part of European Russia and regions of the Far East (Sakhalin Region and Khabarovsk Territory) are characterized by the highest level of risk. Railways in these regions are most affected by the impacts of heavy snowfalls, heavy rains, snow avalanches, landslides, debris flows, and rockfalls.

\subsubsection{Air transport}

The risk of emergencies in air transport depends on the aircraft's technical conditions, air traffic intensity, human factors, meteorological conditions, and seasonality.

The number of air transport accidents and traffic disruptions due to impacts of natural hazards was included in the calculation of the total risk indicator. For the risk analysis, 70 emergency situations were taken into consideration. The main triggers of these emergencies and the regions of their occurrence were identified in Sect. 3.1.3.

\subsubsection{Water transport}

The risk of emergencies in water transport depends on the technical conditions of vessels, traffic intensity, human factors, climatic conditions, and seasonality.

Water transport accidents due to natural impacts were also included in the calculation of the total risk of transport accidents and disruptions. For the risk analysis, 70 emergency situations were taken into consideration. The main triggers of these emergencies and the regions of their occurrence were identified in Sect. 3.1.4.

\subsubsection{The total risk}

Additionally, the total risk of transport accidents and traffic disruptions was assessed for the area of Russia. Occurrence frequencies of accidents and disruptions in all the aboveexamined types of transport from 1992 to 2018 were used as risk indicators.

For the total risk analysis, 838 emergency situations of various scales and severity caused by the impacts of natural 


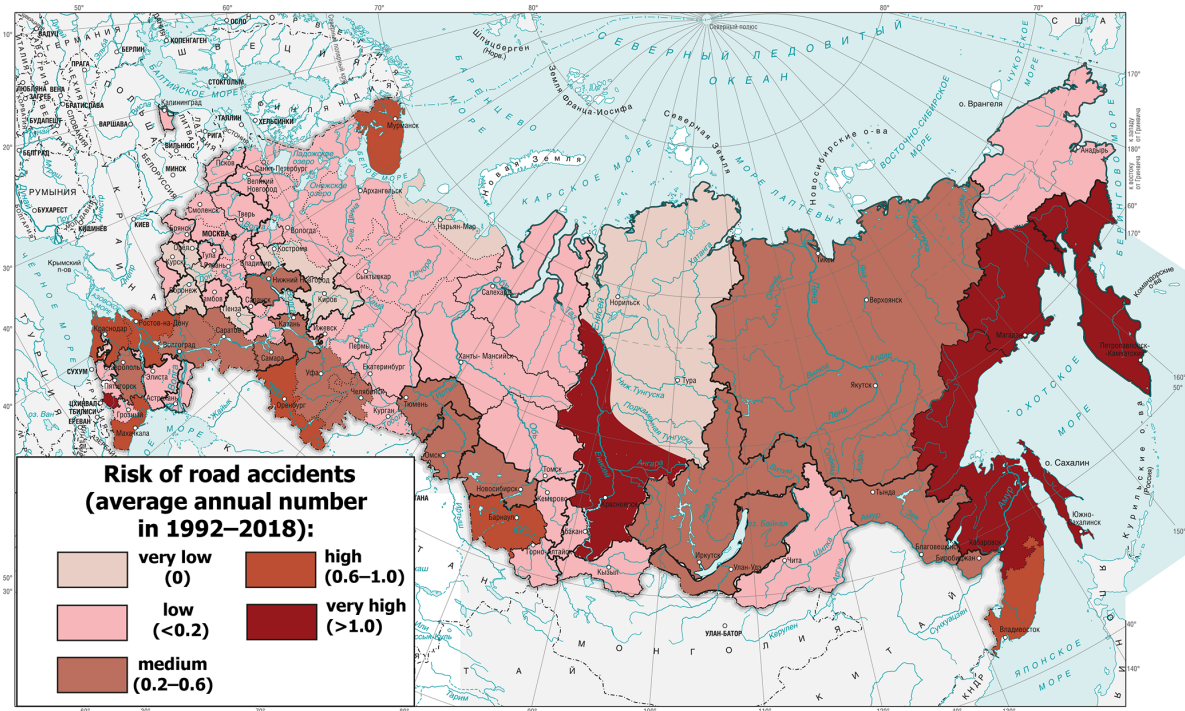

Figure 4. Risk of road accidents and traffic disruptions triggered by natural hazards in the RF (base map @ DIK - Publishing House: Design. Information. Cartography).

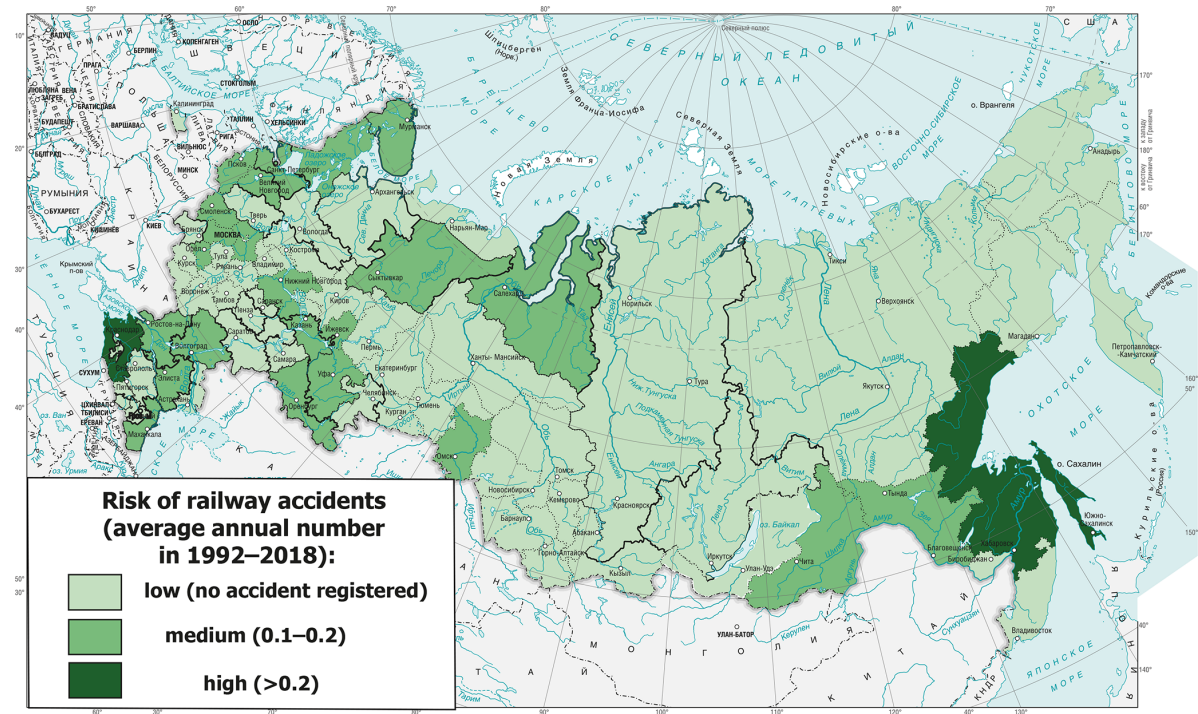

Figure 5. Risk of railway accidents and traffic disruptions triggered by natural hazards in the RF (base map @ DIK - Publishing House: Design. Information. Cartography).

hazards on transport infrastructure were taken into consideration. The main triggers of these accidents were identified in Sect. 3.1 and shown in Table 1; annual average numbers of these events were calculated for each federal region as well as the average for Russia.

All the federal regions were divided into five groups by their risk levels. The procedure for selecting groups was described in Sect. 2.2.

Figure 6 shows the resulting map. Regions of the Far East (Kamchatka, Khabarovsk, and Primorye territories; Magadan and Sakhalin regions), Krasnoyarsk Territory in the southern part of central Siberia, Murmansk Region in the northern and Krasnodar Territory in the southern part of European Russia, and the Republic of North Ossetia - Alania in the North Caucasus have the highest level of risk. The transport infrastructure in these regions is most affected by the adverse impacts of natural hazards listed in Table 1, primarily those of a hydrometeorological genesis. Kamchatka, Khabarovsk, and Primorye Territories, as well as Sakhalin Region, are characterized by the most dangerous meteorological combinations of heavy precipitation and strong winds. In the Kamchatka, Krasnodar, and Primorye territories, the most intense rains are recorded. In winter, the heaviest snowfalls happen in all the above regions. In spring and early 


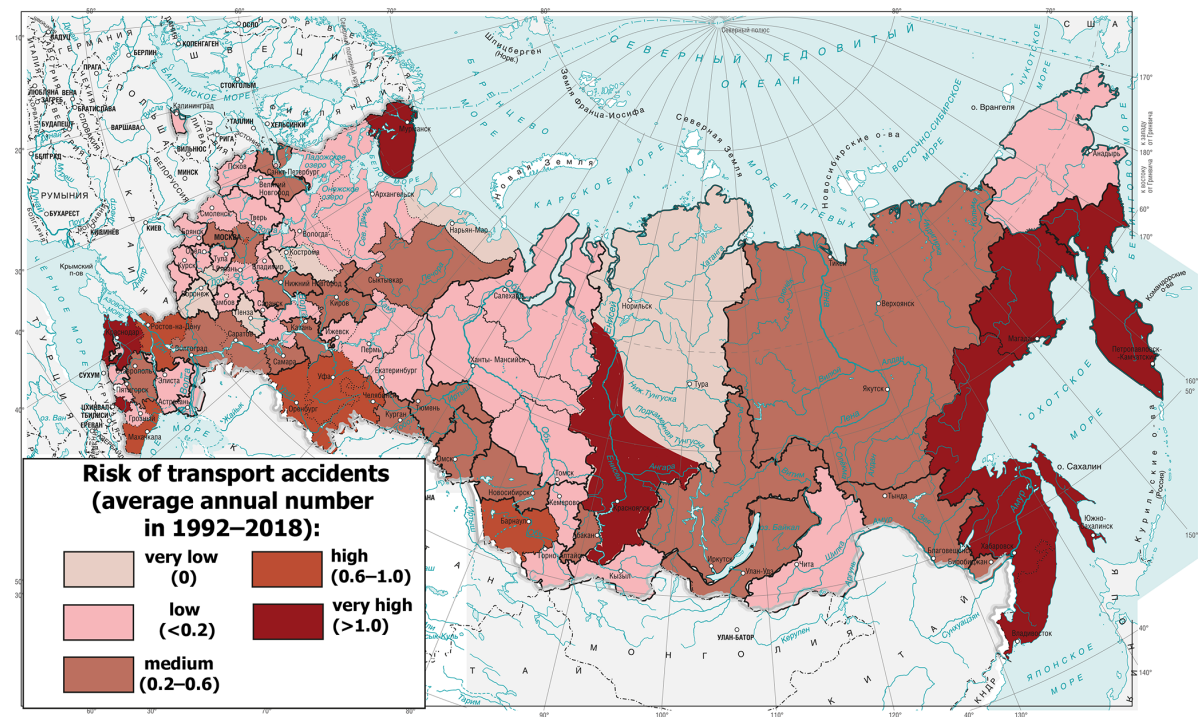

Figure 6. Risk of transport accidents and disruptions triggered by natural hazards in the RF (base map (C) DIK - Publishing House: Design. Information. Cartography).

autumn, the Khabarovsk, Krasnodar, and Primorye territories are subject to catastrophic floods. Kamchatka is most at risk of volcanic eruptions. The Republic of North Ossetia Alania and Sakhalin Region are characterized by the highest avalanche and debris flow activity. All of the mentioned natural hazards trigger accidents and lead to delay in the transportation of passengers and goods by road, railway, air, and water transport. In addition, Kamchatka, Sakhalin, the southern part of Siberia, and the North Caucasus are among the most seismically active regions of Russia; during the study period, no traffic accidents due to earthquakes were recorded, but their possibility should be taken into account.

\section{Concluding remarks and discussion}

The contributions of various natural hazards to occurrences of different types of transport accidents and traffic disruptions including road, railway, air, and water transport are revealed. Among all the identified types of natural hazards, hydrometeorological hazards such as heavy snowfalls and rains and floods and ice phenomena, as well as dangerous exogenous slope processes including snow avalanches, debris flows, landslides, and rockfalls, have the largest contributions to transport accidents and disruptions. The most dangerous is the combination of heavy precipitation and strong winds.

An annual average frequency of occurrences of emergency situations of various scales and severity is applied in this study among all possible methods for assessing risk. Unlike methods that assess risk by measuring its components such as hazard, exposure, and vulnerability, this approach takes into account the resulting consequences of the above factors and the probability of these consequences. Transport accidents and disruptions are considered in this case as consequences of natural hazard impacts on transport infrastructure that is exposed and vulnerable to these impacts. The risk index is calculated as an annual average number of emergency situations caused by natural hazard impacts in each federal region and for each type of transport. Thus, the index used combines both the probability and the severity of the adverse impacts of natural hazards on transport infrastructure, as well as the vulnerability of infrastructure to these adverse impacts, resulting in accidents and malfunctions. Using this method, it is possible to compare different regions and identify deficiencies that need to be addressed.

Regional differences in the risk of transport accidents between Russian federal regions were found. All the federal regions were divided into groups by their risk levels of road and railway accidents, as well as by the total risk of transport accidents and traffic disruptions due to natural hazard impacts. The resulting maps were created and analyzed.

The Kamchatka, Khabarovsk, Krasnodar, Krasnoyarsk, Primorye territories; Magadan, Murmansk, and Sakhalin regions; and Republic of North Ossetia - Alania are characterized by the highest risk of transport accidents and traffic disruptions caused by natural events. Emergencies of various scales occur in these regions on average more often than once a year (Fig. 6). The Chelyabinsk, Orenburg, and Rostov regions; Altai Territory; republics of Dagestan and Bashkortostan; and Moscow have a high risk level with an average probability of one event in 1-2 years $\left(0.6-1.0\right.$ events $\left.\mathrm{yr}^{-1}\right)$.

For the study period of 1992 to 2018, the database mainly recorded events caused by hydrometeorological and exogenous natural hazards. With high values of the risk index, Kamchatka, Sakhalin, the North Caucasus, and southern 
Siberia are also among the most seismically active regions of Russia, which further increases the likelihood of emergencies in these regions in the case of earthquakes. It is in these regions that the necessary measures should first be taken to reduce the vulnerability of transport infrastructure to undesirable natural impacts and increase the level of protection and preparedness.

Under conditions of observed and forecasted global and regional climate changes, adverse and hazardous natural impacts on various facilities of transport infrastructure, primarily from natural hazards of meteorological and hydrological origin, as well as other natural events triggered by them such as landslides, snow avalanches, and debris flows, are expected to increase (Malkhazova and Chalov, 2004; Yakubovich et al., 2018). Other factors, such as a growing transportation network, increased traffic, and a lack of funding, will also lead to an increase in adverse impacts, especially with further development of transport infrastructure to areas with high levels of natural risk. In this regard, the continuous monitoring and assessment of natural hazard impacts is especially relevant and important.

Only severe accidents leading to an emergency situation were considered in this study due to a lack of data on small events. This gap should be filled in future research because small events can also cause great damage to the infrastructure and trigger accidents and traffic interruptions (Voumard et al., 2018).

Effects of global processes such as space weather on the transport infrastructure facilities, especially on electronics and automatic machinery, were not taken into consideration because these events were not recorded in the database. In the future, these impacts should be also investigated; the risk of these events should be considered in the risk assessment.

Data availability. The data used in this study have been collected by the author in an electronic database, which is not available publicly.

Competing interests. The author declares that there is no conflict of interest.

Special issue statement. This article is part of the special issue "Natural hazard impacts on technological systems and infrastructures". It is a result of the EGU General Assembly 2019, Vienna, Austria, 7-12 April 2019.

Financial support. This research has been supported by the Lomonosov Moscow State University (grant no. I.7 AAAA-A16116032810093-2, "Mapping, modeling and risk assessment of dangerous natural processes").
Review statement. This paper was edited by Maria Bostenaru Dan and reviewed by two anonymous referees.

\section{References}

Anan'in, I. V. and Merzlyi, A. M.: Tectonically active zone of Russian northern areas and their impact on air crashes, Ecology of Russian Northern Areas, Problems, situation forecast, ways of development, decisions, Proceedings, Arkhangelsk, 2, 4-8, 2002 (in Russian).

Andersson, A. K. and Chapman, L.: The impact of climate change on winter road maintenance and traffic accidents in West Midlands, UK, Accident Anal. Prev., 43, 284-289, 2011.

Andrey, J.: Long-term trends in weather-related crash risks, J. Transp. Geogr., 18, 247-258, 2010.

Aron, M., Bergel-Hayat, R., Saint Pierre, G., and Violette, E.: Added risk by rainy weather on the roads of Normandy-centre region in France, Proceedings of 11th WCTR, World Conference on Transport Research, 24-28 June 2007, University Berkeley, California, USA, 2007.

Arosio, M., Martina, M. L. V., and Figueiredo, R.: The whole is greater than the sum of its parts: a holistic graphbased assessment approach for natural hazard risk of complex systems, Nat. Hazards Earth Syst. Sci., 20, 521-547, https://doi.org/10.5194/nhess-20-521-2020, 2020.

Arrighi, C., Brugioni, M., Castelli, F., Franceschini, S., and Mazzanti, B.: Urban micro-scale flood risk estimation with parsimonious hydraulic modelling and census data, Nat. Hazards Earth Syst. Sci., 13, 1375-1391, https://doi.org/10.5194/nhess13-1375-2013, 2013.

Bergel-Hayat, R., Debbarh, M., Antoniou C., and Yannis, G.: Explaining the road accident risk: Weather effects, Accident Anal. Prev., 60, 456-465, 2013.

Bíl, M., Kubeček, J., and Andrášik, R.: An epidemiological approach to determining the risk of road damage due to landslides, Nat. Hazards, 73, 1323-1335, 2014.

Bil, M., Andrasik, R., Nezval V., and Bilova M.: Identifying locations along railway networks with the highest tree fall hazard, Appl. Geogr., 87, 45-53, https://doi.org/10.1016/j.apgeog.2017.07.012, 2017.

Brenot, H., Theys, N., Clarisse, L., van Geffen, J., van Gent, J., Van Roozendael, M., van der A, R., Hurtmans, D., Coheur, P.-F., Clerbaux, C., Valks, P., Hedelt, P., Prata, F., Rasson, O., Sievers, K., and Zehner, C.: Support to Aviation Control Service (SACS): an online service for near-real-time satellite monitoring of volcanic plumes, Nat. Hazards Earth Syst. Sci., 14, 1099-1123, https://doi.org/10.5194/nhess-14-1099-2014, 2014.

Brodsky, H. and Hakkert, A. S.: Risk of a road accident in rainy weather, Accident Anal. Prev., 20, 161-176, 1988.

Budetta, P. and Nappi, M.: Comparison between qualitative rockfall risk rating systems for a road affected by high traffic intensity, Nat. Hazards Earth Syst. Sci., 13, 1643-1653, https://doi.org/10.5194/nhess-13-1643-2013, 2013.

Bunce, C. M., Cruden, D. M., and Morgenstern, N. R.: Assessment of the hazard from rock fall on a highway, Can. Geotech. J., 34, 344-356, 1997. 
Chakrabarty, N. and Gupta, K.: Analysis of Driver Behaviour and Crash Characteristics during Adverse Weather Conditions, Procd. Soc. Behv., 104, 1048-1057, 2013.

Desiatov, V. P., Osipov, A. I., and Suzdal'skaya, O. V.: Solar Activity and Death-Rate Statistics, The Sun, Electricity, Life, Proceedings of Memorial Readings devoted to A. L. Chijevskii, Moscow, Russia, 90-92, 1972 (in Russian).

Eckert, N., Keylock, C. J., Bertrand, D., Parent, E., Faug, T., Favier, T., and Naaim, M.: Quantitative risk and optimal design approaches in the snow avalanche field: Review and extensions, Cold Reg. Sci. Technol., 79-80, 1-19, 2012.

Edwards, J. B.: Weather-related road accidents in England and Wales: a spatial analysis, J. Transp. Geogr., 4, 201-212, 1996.

Eidsvig, U. M. K., Kristensen, K., and Vangelsten, B. V.: Assessing the risk posed by natural hazards to infrastructures, Nat. Hazards Earth Syst. Sci., 17, 481-504, https://doi.org/10.5194/nhess-17481-2017, 2017.

EMERCOM: Atlas of natural and technological hazards and risks. The Russian Federation, Publishing House: Design. Information. Cartography, Moscow, Russia, 2010.

Epov, A. B.: Regularities in Occurrence of Technological Emergencies and their Relationship with Natural Processes, Problems of Safety under Emergencies, 12, 14-20, 1994 (in Russian).

Falter, D., Schröter, K., Dung, N. V., Vorogushyn, S., Kreibich, H., Hundecha, Y., Apel, H., and Merz, B.: Spatially coherent flood risk assessment based on long-term continuous simulation with a coupled model chain, J. Hydrol., 524, 182-193, https://doi.org/10.1016/j.jhydrol.2015.02.021, 2015.

Federal Law of the Russian Federation N 16-FZ "On Transport Security", as amended on 12 February 2019, adopted by the State Duma of the Russian Federation on 19 January 2007, available at: https://legalacts.ru/doc/ federalnyi-zakon-ot-09022007-n-16-fz-o/ (last access: 10 July 2020), 2019 (in Russian).

FSSS: Russian Statistical Yearbook 2018: Stat.book, Rosstat, Moscow, Russia, 2018.

FSSS: Regions of Russia. Socio-economic indicators 2019, Rosstat, Moscow, Russia, 2020.

Gill, J. C. and Malamud, B. D.: Hazard interactions and interaction networks (cascades) within multi-hazard methodologies, Earth Syst. Dynam., 7, 659-679, https://doi.org/10.5194/esd-7659-2016, 2016.

Girina, O. A., Manevich, A. G., Melnikov, D. V., Nuzhdaev, A. A., and Petrova, E. G.: 2016 volcano eruptions in Kamchatka and the Northern Kuriles and their danger to aviation, J. Volcanol. Seismol., 3, 34-48, 2019.

Gordeev, E. I. and Girina, O. A., Volcanoes and the threat they pose for aircraft, Vestn. Ros. Akad. Nauk+, 84, 134-142, https://doi.org/10.7868/S0869587314020121, 2014.

Govorushko, S. M.: Natural processes and Human impacts: Interaction between Humanity and the Environment, Springer, Dordrecht, the Netherlands, 2012.

Hong, L., Ouyang, M., Peeta, S., He, X., and Yan, Y.: Vulnerability assessment and mitigation for the Chinese railway system under floods, Reliab. Eng. Syst. Safe., 137, 58-68, 2015.

IPCC: Managing the Risks of Extreme Events and Disasters to Advance Climate Change Adaptation. A Special Report of Working Groups I and II of the Intergovernmental Panel on Climate Change, edited by: Field, C. B., Barros, V., Stocker, T. F., Qin,
D., Dokken, D. J., Ebi, K. L., Mastrandrea, M. D., Mach, K. J., Plattner, G.-K., Allen, S. K., Tignor, M., and Midgley, P. M., Cambridge University Press, Cambridge, UK, and New York, NY, USA, 582 pp., 2012.

Jaiswal, P. and van Westen, C. J.: Use of quantitative landslide hazard and risk information for local disaster risk reduction along a transportation corridor: a case study from Nilgiri district, India, Nat. Hazards, 65, 887-913, https://doi.org/10.1007/s11069-0120404-1, 2013.

Jaroszweski, D. and McNamara, T.: The influence of rainfall on road accidents in urban areas: A weather radar approach, Travel Behaviour and Society, 1, 15-21, https://doi.org/10.1016/j.tbs.2013.10.005, 2014.

Kanonidi, H. K., Oraevskii, V. N., Belov, A. V., Gaidash, S. P., and Lobkov, V. L.: Railway Automatic System Failures under Geomagnetic Storms, Problems of Emergency Forecasting, Proceedings, Russian Ministry of Emergencies, Moscow, Russia, 41-42, 2002 (in Russian).

Kaundinya, I., Nisancioglu, S., Kammerer, H., and Oliva, R.: Allhazard guide for transport infrastructure, Transp. Res. Proc., 14, 1325-1334, 2016.

Kellermann, P., Schönberger, C., and Thieken, A. H.: Large-scale application of the flood damage model RAilway Infrastructure Loss (RAIL), Nat. Hazards Earth Syst. Sci., 16, 2357-2371, https://doi.org/10.5194/nhess-16-2357-2016, 2016.

Kishcha, P. V., Ivanov-Cholodny, G. S., and Shelkovnikov, M. S.: Zoning of air crashes, Physical Problems of Ecology, Proceedings, Moscow, Russia, 18-19, 1999.

Liu, B., Siu, Y. L., and Mitchell, G.: Hazard interaction analysis for multi-hazard risk assessment: a systematic classification based on hazard-forming environment, Nat. Hazards Earth Syst. Sci., 16, 629-642, https://doi.org/10.5194/nhess-16-629-2016, 2016.

Ludvigsen, J. and Klæboe, R.: Extreme weather impacts on freight railways in Europe, Nat. Hazards, 70, 767-787, https://doi.org/10.1007/s11069-013-0851-3, 2014.

Malkhazova, S. M. and Chalov, R. S. (Eds.): Geography, Society and Environment. Vol. IV: Natural-Anthropogenic Processes and Environmental Risk, Gorodets Publishing House, Moscow, Russia, 2004

Mattsson, L. G. and Jenelius, E.: Vulnerability and resilience of transport systems - a discussion of recent research, Transport. Res. A-Pol., 81, 16-34, 2015.

Miagkov, S. M.: Geography of Natural Risk, Moscow Univ. Press, Moscow, Russia, 1995 (in Russian).

Ministry of Transport of the Russian Federation: Transport Strategy of the Russian Federation for the period until 2030, as amended on 12 May 2018, available at: https://www.mintrans. ru/documents/3/1009 (last access: 10 July 2020), 2018.

Neal, C., Girina, O., Senyukov, S., Rybin, A., Osiensky, J., Izbekov, P., and Ferguson, G.: Russian eruption warning systems for aviation, Nat. Hazards, 51, 245-262, 2009.

Nogal, M., O'Connor, A., Caulfield, B., and Brazil, W.: A multidisciplinary approach for risk analysis of infrastructure networks in response to extreme weather, Transp. Res. Proc., 14, 78-85, 2016.

Nyberg, R. and Johansson, M.: Indicators of road network vulnerability to storm-felled trees, Nat. Hazards, 69, 185-199, https://doi.org/10.1007/s11069-013-0693-z, 2013. 
Petrova, E.: Natural hazards and technological risk in Russia: the relation assessment, Nat. Hazards Earth Syst. Sci., 5, 459-464, https://doi.org/10.5194/nhess-5-459-2005, 2005.

Petrova, E.: Critical infrastructure in Russia, Geographical analysis of accidents triggered by natural hazards, Environ. Eng. Manag. J., 10, 53-58, 2011.

Petrova, E.: Road accidents in Russia: statistical and geographical analysis, Scientific Annals of "Alexandru Ioan Cuza" University of Iasi, Geography series, 59, 111-123, 2013.

Petrova, E.: Road and railway transport in Russia: safety and risks, AES Bioflux, 7, 259-271, 2015.

Petrova, E. G. and Shiryaeva, A. V.: Road accidents in Moscow: weather impact, AES Bioflux, 11, 19-30, 2019.

Rakha, H., Farzaneh, M., Arafeh, M., Hranac, R., Sterzin, E., and Krechmer, D.: Empirical Studies on Traffic Flow in Inclement Weather, Final Report - Phase I, Virginia Tech Transportation Institute, Blacksburg, USA, 2007.

Redelmeier, D. A. and Raza, S.: Life-threatening motor vehicle crashes in bright sunlight, Medicine, 96, e5710, https://doi.org/10.1097/MD.0000000000005710, 2017.

Satterthwaite, S. P.: An assessment of seasonal and weather effects on the frequency of road accidents in California, Accident Anal. Prev., 8, 87-96, 1976.

Schlögl, M., Richter, G., Avian, M., Thaler, T., Heiss, G., Lenz, G., and Fuchs, S.: On the nexus between landslide susceptibility and transport infrastructure - an agent-based approach, Nat. Hazards Earth Syst. Sci., 19, 201-219, https://doi.org/10.5194/nhess-19201-2019, 2019.

Schneiderbauer, S. and Ehrlich, D.: Risk, hazard and people's vulnerability to natural hazards: A review of definitions, concepts and data, Eur. Comm. Jt. Res. Centre. Eur., 40, 21410, https://doi.org/10.1007/978-3-540-75162-5_7, 2004.
Shabou, S., Ruin, I., Lutoff, C., Debionne, S., Anquetin, S., Creutin, J.-D., and Beaufils, X.: MobRISK: a model for assessing the exposure of road users to flash flood events, Nat. Hazards Earth Syst. Sci., 17, 1631-1651, https://doi.org/10.5194/nhess17-1631-2017, 2017.

Shiryaeva, A. V.: Meteorological Conditions for Functioning of Automobile Transport in Moscow and Moscow Oblast, Izvestia Russia Academy of Sci., 6, 94-101, 2016 (in Russian).

Shnyparkov, A. L.: Methods of natural risk evaluation, in: Geography, Society and Environment, edited by: . Malkhazova, S. M. and Chalov, R. S., vol. IV: Natural-Anthropogenic Processes and Environmental Risk, Gorodets Publishing House, Moscow, Russia, 349-356, 2004.

Spasova, Z. and Dimitrov, T.: The effects of precipitation on traffic accidents in Sofia, Bulgaria, Asklepios, International Annual for History and Philosophy of Medicine, 1, 76-81, 2015.

Tanner, J. C.: Effect of Weather on Traffic Flow, Nature, 169, 107, https://doi.org/10.1038/169107a0, 1952.

Voumard, J., Derron, M.-H., and Jaboyedoff, M.: Natural hazard events affecting transportation networks in Switzerland from 2012 to 2016, Nat. Hazards Earth Syst. Sci., 18, 2093-2109, https://doi.org/10.5194/nhess-18-2093-2018, 2018.

WHO: The top 10 causes of death, available at: http://www.who. $\mathrm{int} /$ mediacentre/factsheets/fs310/en/ (last access: 10 July 2020), 2017.

Yakubovich, A., Trofimenko, Y., and Pospelov P.: Principles of developing a procedure to assess consequences of natural and climatic changes for transport infrastructure facilities in permafrost regions, Transp. Res. Proc., 36, 810-816, 2018.

Yang, J., Sun, H., Wang, L., Li, L., and Wu, B.: Vulnerability Evaluation of the Highway Transportation System against Meteorological Disasters, Procd. Soc. Behv., 96, 280-293, 2013. 